nature

4 May 1978

\title{
Too many official secrets
}

ANY of the many thousands of scientists and engineers employed by the British government, either directly or indirectly, would be guilty of a misdemeanour if he or she communicated a "code word, pass word, sketch, plan, model, article, note, document or information to any person other than a person to whom he is authorised to communicate it, or a person to whom it is, in the interest of the State, his duty to communicate it". So states Section 2 of the Official Secrets Act and to press the point home posters at workplaces declare "You must not talk about or pass on information about your work unless you are authorised to do so", which is a more restricted reading of the meaning of the act. But every day scientists do just that in the course of communicating with the outside world, whilst others unsure about their position vis-à-vis the act are genuinely inhibited from talking about the implications of their work, criticising government policy in any way, writing to the press to correct genuine errors and so on. The Official Secrets Act is occasionally looked at (as, for instance, by the Franks Commission in 1971-2) and there are now and then promises of a White Paper proposing new legislation (one is due at the moment, but no delivery date is mentioned). Meanwhile, a law is variously ignored and feared; this cannot be for the common good.

Few would deny that as far as Britain's defence research goes, those who have chosen to work in the field are probably ill-advised to start delivering passwords, models and so on to the military attachés of certain embassies in London. And whilst clearance of scientific manuscripts for publication is an irksome business, involving people who know little or nothing of the content, there are few complaints about the unreasonable withholding of approval. It is only when one moves into the more informal channels of communication that the ground becomes more shaky. If an employee of Harwell who is a parent is asked to hand out the prizes after Sports Day and make a few encouraging remarks to the assembled company, should those remarks be cleared? If a scientist spots a technical error or a misunderstanding in a press report on a sub- ject in which he is generally competent, should approval be sought before any approach is made to the media to make a correction? If it seems that incompetence in some part of the civil service is severely holding up progress on some project which is generally regarded as desirable, does a potential whistle-blower have to clear any remarks he may wish to make with the very authorities whom he wishes to criticise? The answer to all these questions is yes, and accounts for the almost invisibility of many civil servants-not perhaps a severe loss to sports days, but certainly a severe impediment to public debate. Of course, many scientists working for the government are very helpful indeed, willing to answer questions directly, willing to talk freely about their work and its implications. But few can afford to be seen to be doing so when the issue at stake is at all controversial.

One of the problems is the extraordinary generality of the word 'information'. Anything from how to make a nuclear device to the identity of the tea-lady comes within this category, and perhaps most troubling, 'information' need not simply be basic facts but could be interpreted as almost any general understanding of the way things are that accrues after working anywhere for a period of time. Likewise there is ambiguity in the concession that information can be transferred, unauthorised, "if it is in the interest of the State". If the boss is incompetent and no-one within the organisation will listen, the state's interest is probably served by telling all, as a last resort.

Most people who work for large organisations get used to 'the system' - an almost totally unwritten code of what should and shouldn't be done, what competitors may not be told, how much the organisation should be criticised, how much defended. Organisations do not suffer badly from leaving their employees to work out from common sense what the system is. Civil servants also work within a system, applying common sense much of the time in their external relations. But over it all hovers an ambiguous act which can and often does over-rule common sense. The time has surely come to cut back on the act's scope. 